\title{
Possible Role of Breakdown Products of Phloridzin in Symptom Development by Valsa ceratosperma*
}

\author{
Hiroki Koganezawa** and Tsutomu Sakuma** \\ 小金沢碩城**・佐久間 勉**：フロリジンのリンゴ腐らん病菌 \\ による分解産物が病徴発現に関与する可能性について*
}

\begin{abstract}
Solution of diethyl ether extracts from culture filtrate of Valsa ceratosperma, a causal agent of apple Valsa canker, grown in a medium containing apple bark components caused similar bark necrosis to the canker on naturally infected apple trees. Three toxic substances were purified from culture extracts by column chromatography and were identified by co-chromatography and by ultraviolet absorption spectra. The toxic substances included phloretic acid ( $p$-hydroxypropionic acid), $p$-hydroxybenzoic acid and protocatechuic acid which are known to be breakdown products of phloridzin. In cut stem bioassay these compounds showed a toxicity only in high concentrations. The toxicities of the compounds were not host specific.
\end{abstract}

(Received February 2, 1982)

Key Words : toxin, Valsa ceratosperma, apple, phloridzin.

\section{Introduction}

Valsa ceratosperma (Tode ex Fr.) Maire causes a canker on apple ${ }^{18)}$, pear ${ }^{15)}$ and quince $^{13)}$. It has been isolated from various broad-leaved trees ${ }^{10)}$. The fungus infects the trees through wounds such as the pruning ends or fruit scars ${ }^{16)}$. The infected bark first exhibits a swollen, water-soaked appearance. The lesion yields to the push of a finger and smells like alcohol. The epidermis can easily be scraped off, exposing some discolored tissue beneath. Later lesion dries up and becomes sunken with cracks between the healthy and the diseased portion. Longitudinal browning and necrosis develop in the xylem. In spring when most of the canker begins to develop it is almost impossible to isolate the fungus from the brown-colored xylem tissue under the healthy periderm ${ }^{17)}$. How $V$. ceratosperma induces canker formation has not been clear. Okuno and his colleagues ${ }^{12)}$ isolated isocoumarin derivatives from culture extracts of $V$. ceratosperma but the compounds did not induce bark necrosis identical to the natural canker. We therefore tried to isolate phyotoxic substances from culture containing the

\footnotetext{
* Contribution No. C-70, Fruit Tree Research Station 果樹試験場業績番号 : C-70

A part of this paper was presented at the Annual Meeting of the Phytopathological Society of Japan, April 1, 1981

** Morioka Branch, Fruit Tree Research Station, Shimokuriyagawa, Morioka 020-01, Japan 果樹 試験場盛岡支場
} 
decoction of apple bark, and report here that breakdown products of phloridzin accumulated in the culture and caused similar bark necrosis to the canker on naturally infected apple trees. Similar results were obtained independently by Ohtake et al. ${ }^{11)}$

\section{Materials and Methods}

Bioassay. Cut stem assay was used for measuring toxicity. Excised apple shoots, $15 \mathrm{~cm}$ long with four to five terminal leaves, were placed in vials containing a $10 \mathrm{ml}$ solution of toxic substances. After 48 hours, the length of necrosis appearing on the surface of the bark was measured. In addition to apple shoots, cut stems from 8 other species were also used to determine their sensitivity to the toxic substances.

Toxin production in culture. $\quad V$. ceratosperma was obtained from a naturally infected apple tree (cv. Starking Delicious). Isolate designated as V 2031 was maintained on potato dextrose agar slant at $4 \mathrm{C}$. The medium used in the experiment was prepared as follows. The bark of apple trees (cv. Jonathan) was dried in an oven at $60 \mathrm{C}$ overnight and ground to pass through a $1 \mathrm{~mm}$ screen in a Wiley mill. The bark powder (100 g) was boiled in 1 liter distilled water for one hour and then filtered. One gram of dextrose per $100 \mathrm{ml}$ was added to the filtrate. The toxin was produced in $500 \mathrm{ml}$ Sakaguchi flasks, each containing $100 \mathrm{ml}$ of the medium which was inoculated with a $0.5 \mathrm{~cm}$ diameter plug cut from the edge of a three-day-old colony of $V$. ceratosperma growing on potato dextrose agar. Cultures were incubated in a standing culture for two days and later in a shaking culture in the dark at $25 \mathrm{C}$. Ethanol, twice the volume of the entire culture, was added and filtered to remove mycelium and a viscouse material produced by the fungus. The filtrate was evaporated in vacuo to near dryness, then diluted to $50 \mathrm{ml}$ with water. The dilution was acidified to $\mathrm{pH} 2.5$ with $\mathrm{HCl}$ and extracted twice with an equal volume of diethyl ether. The ether phases were combined and evaporated to dryness. The residue was resuspended in $20 \mathrm{ml}$ of water, then filtered to remove the insoluble precipitate and tested for toxicity.

Separation of toxic substances. Ether extracts of the culture filtrate were examined by paper chromatography. A portion of the preparation was streaked across a $40 \times 40 \mathrm{~cm}$ strip of Whatman No. 1 chromatography paper. Chromatography was carried out in an ascending manner with $n$-propanol/ $\mathrm{NH}_{4} \mathrm{OH} /$ water $(6: 3: 1, \mathrm{v} / \mathrm{v})$ and continued until the solvent front had migrated $25 \mathrm{~cm}$. The paper was air-dried for one hour and divided into 10 sections from which toxic substances were eluted with distilled water and bioassayed for toxicity. In paper chromatography there was a tendency for the $\mathrm{Rf}$ value of each compound to be lower than the $\mathrm{Rf}$ value of the sample in rechromatography of each eluate. The ether extracts were loaded on a $2.5 \times 15 \mathrm{~cm}$ column of polyvinylpolypirroridone and eluted with a linear gradient of 0 to 100 percent methanol in water. The eluate was monitored by ultraviolet spectrophotometer. The fractions that showed the same UV absorption spectrum were pooled and concentrated in vacuo, adjusted to a $20 \mathrm{ml}$ volume with distilled water and bioassayed for toxicity or analyzed by thin layer chromatography.

Identification of toxic substances. Portions of the preparation (10 microliter portions) obtained by column chromatography were spotted on silica gel with fluorescent materials (Wako gel FM plate, Wako Pure Chemical Ind. Ltd.) with 


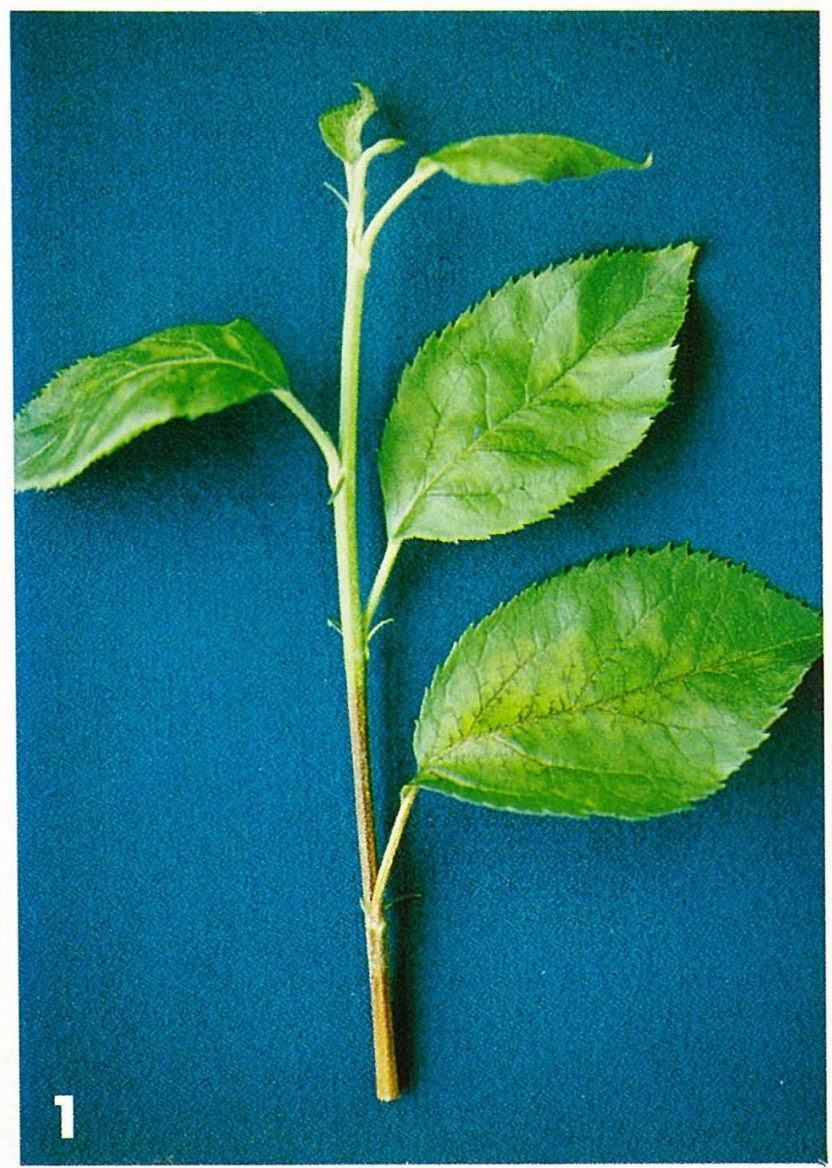

Fig. 1. Apple shoot treated with ether extract of culture filtrate.

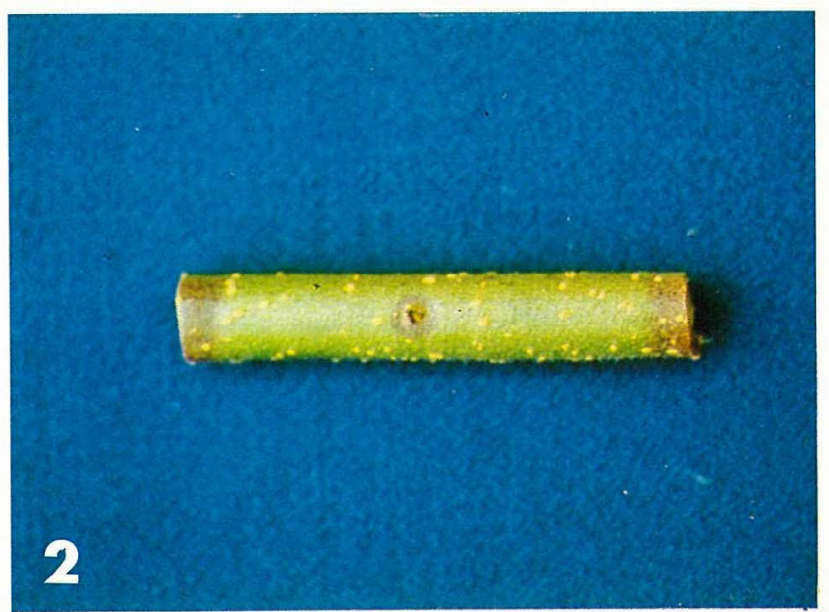

Fig. 2. Apple shoot segment immersed in solution of ether extract of culture filtrate. 
authentic samples of phloretic acid, $p$-hydroxybenzoic acid and protocatechuic acid. The plates were developed in ethanol/ $\mathrm{NH}_{4} \mathrm{OH} /$ water $(8: 1: 1, \mathrm{v} / \mathrm{v})$ and viewed under UV light (Topcon Pan UV lamp, PUV-1, Tokyo Kogaku Kikai K. K.). The authentic sample of phloretic acid was prepared by hydrogenation of $p$-coumaric acid. The ultraviolet absorption spectrum was measured with a Hitachi spectrophotometer, Model 624.

\section{Results}

\section{Biological properties of toxic substances}

When apple shoots were placed in vials containing $10 \mathrm{ml}$ of ether extracts of the culture filtrate, necrosis appeared from the base within 3 hours and extended toward the apex of the cuttings (Fig. 1). Occasionally necrosis developed along the side to which the lowest leaves remained attached. The cuttings did not show a wilt within 2 days. But at high concentrations of the toxic substances, veinal necrosis occurred at the basal end of the leaf. Observation of freehand section of affected stems revealed that browning first appeared in vascular bundles.

The relation between the square root of the length of bark necrosis at 2 days after toxin treatment and the $\log$ of toxin concentration was linear at certain toxin concentrations (Fig. $3)$.

In another experiment, whole shoot segments were immersed in a solution of the ether extract. Necrosis appeared only from the cut ends and from a pinpoint injury made by an eyeleteer (Fig. 2).

Toxic substance production in culture

The time-course of toxin accumulation was followed by collecting filtrates at definite days after inoculation with mycelium plugs of

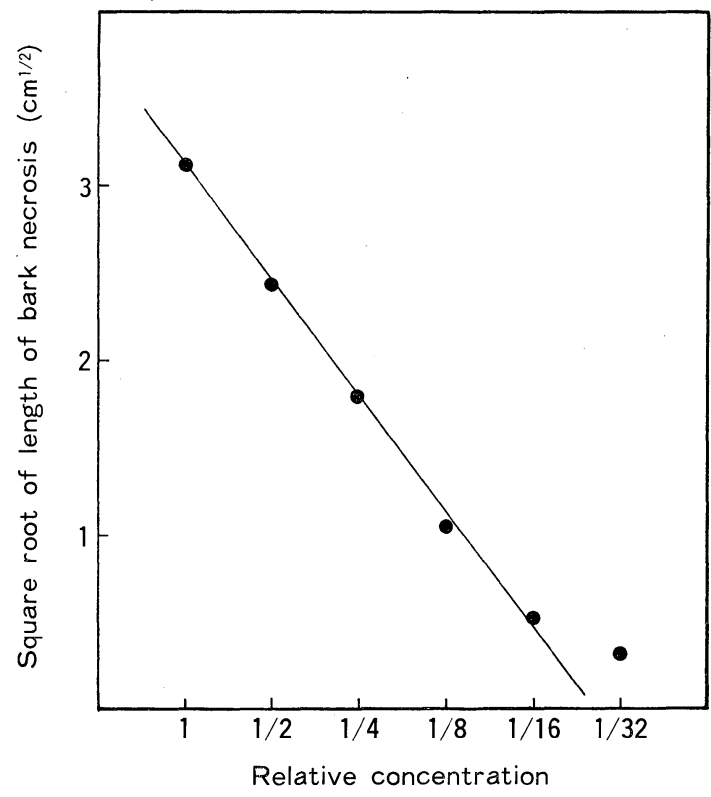

Fig. 3. Relation between the length of bark necrosis and the concentration of toxin complex.

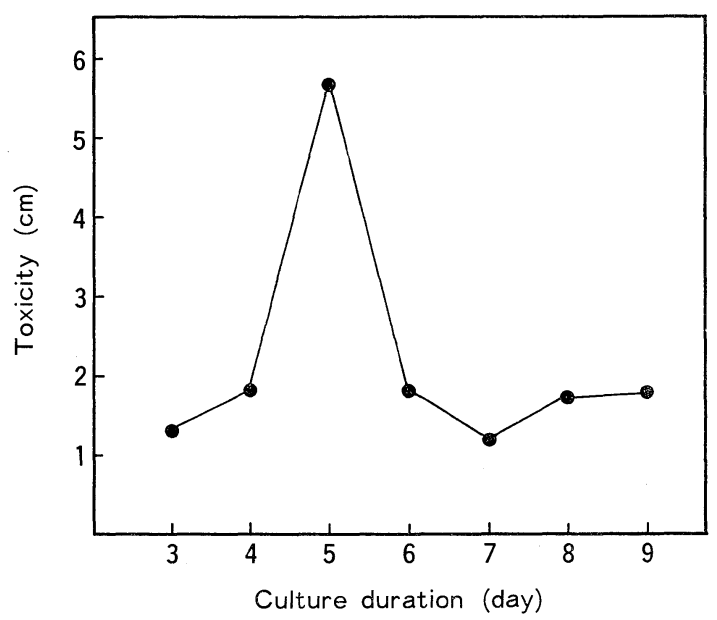

Fig. 4. Production of toxin in bark decoction glucose media following inoculation with Valsa ceratosperma. Toxicity was tested by cut stem assay and expressed as the length of bark necrosis. 
$V$. ceratosperma. Ether extracts were tested for toxicity by cut stem assay. Toxicity reached its maximum at 5 days after inoculation of the fungus and decreased gradually in culture extracts obtained after longer times (Fig. 4). Slight toxicity was detectable in extracts from the control medium. Bark necrosis caused by extracts from the control medium was less than $0.5 \mathrm{~cm}$ long, while that caused by extracts from the inoculated medium reached a maximum of $6 \mathrm{~cm}$.

\section{Separation of the toxic substance}

When toxin was separated in paper chromatography, three toxic activities were detected (Table 1). Similarly column chromatography of ether extract revealed three toxic compounds (Table 2). The samples obtained by column chromatography were subjected to thin layer co-chromatography with authentic samples. The three components were identified as phloretic acid, $p$-hydroxybenzoic acid and protocatechuic acid on the basis of their $\mathrm{Rf}$ values and the color spot under ultraviolet light. The identification was further confirmed by a comparison of the ultraviolet absorption spectra of unknown compounds with those of authentic samples.

\section{Lowest effective concentration of toxic compounds}

To measure the lowest dose that will induce bark necrosis in cut stem assay, four compounds were tested. The lowest level detected was $250 \mathrm{ppm}$ for phloretic acid and

Table 1. Toxicity in water eluates of the paper chromatogram of ether extract

\begin{tabular}{|c|c|c|c|c|c|c|c|c|c|c|}
\hline $\mathrm{Rf}$ value & $0.0 \sim 0.1$ & $0.1 \sim$ & $0.2 \sim$ & $\begin{array}{c}0.3 \sim \\
0.4\end{array}$ & $\begin{array}{r}0.4 \sim \\
0.5\end{array}$ & $\begin{array}{r}0.5 \sim \\
0.6\end{array}$ & $0.6 \sim$ & $\begin{array}{r}0.7 \sim \\
0.8\end{array}$ & $\begin{array}{r}0.8 \sim \\
0.9\end{array}$ & $\begin{array}{r}0.9 \sim \\
1.0\end{array}$ \\
\hline Toxicity $^{a}$ & $0 \mathrm{~cm}$ & 0.5 & 0 & 0.3 & 0.4 & 1.9 & 2.4 & 0.2 & 0 & 0 \\
\hline
\end{tabular}

a) Toxicity was tested by cut stem assay and expressd as the length of bark necrosis. Toxicity of Rf $0.1 \sim 0.2,0.3 \sim 0.5$ and $0.5 \sim 0.8$ was attributed to protocatechuic acid, $p$-hydroxybenzoic acid and phloretic acid, respectively.

Table 2. Toxicity in eluates of the column chromatogram of ether extract

\begin{tabular}{lllllllllll}
\hline \hline Fraction No. & 1 & 2 & 3 & 4 & 5 & 6 & 7 & 8 & 9 & 10 \\
\hline Toxicity $^{\mathrm{a}}$ & $0 \mathrm{~cm}$ & 0 & 4.7 & 0 & 0 & 0.3 & 0 & 0 & 0.7 & 0
\end{tabular}

a) Toxicity was tested by cut stem assay and expressed as the length of bark necrosis. Toxicity of fraction 3, 6 and 9 was attributed to phloretic acid, p-hydroxybenzoic acid and protocatechuic acid respectively.

Table 3. Symptom production by different dosages of breakdown products of phloridzin in cut stem bioassay

\begin{tabular}{ccccc}
\hline \hline Concentration & Phloretic acid & $\begin{array}{c}p \text {-Hydroxybenzoic } \\
\text { acid }\end{array}$ & $\begin{array}{c}\text { Protocatechuic } \\
\text { acid }\end{array}$ & Phloroglucin \\
\hline $4,000 \mathrm{ppm}$ & $8.7 \mathrm{~cm}^{\mathrm{a}}$ & 8.9 & 5.1 & 2.7 \\
2,000 & 5.3 & 7.5 & 2.3 & 0.1 \\
1,000 & 2.9 & 3.9 & 0.7 & 0.0 \\
500 & 1.1 & 2.1 & 0.2 & 0.0 \\
250 & 0.2 & 0.1 & 0.0 & 0.0 \\
125 & 0.0 & 0.0 & 0.0 & 0.0 \\
\hline
\end{tabular}

a) Toxicity was tested by cut stem assay and expressed as the length of bark necrosis. 
Table 4. Sensitivity of various plant species to breakdown products of phloridzin

\begin{tabular}{lccc}
\hline \hline Plant species & Phloretic acid & $\begin{array}{c}\text { p-Hydroxybenzoic } \\
\text { acid }\end{array}$ & $\begin{array}{c}\text { Protocatechuic } \\
\text { acid }\end{array}$ \\
\hline Pyrus communis (Pear) & $3.4 \mathrm{~cm}^{\text {a) }}$ & 6.5 & 1.9 \\
Cydonia oblonga (Quince) & 15.0 & 15.0 & 11.3 \\
Prunus mume (Japanese apricot) & 7.3 & 6.2 & 3.1 \\
Prunus avium (Cherry) & 11.9 & 11.4 & 1.6 \\
Vitis vinifera (Grape) & 3.0 & 9.2 & 2.0 \\
Castanea crenata (Chestnut) & 11.2 & 13.9 & 2.4 \\
Morus bombycis (Mulberry) & 8.2 & 12.3 & 3.2 \\
Juglans sp. (Walnut) & 15.0 & 15.0 & 10.1
\end{tabular}

a) Toxicity was tested by cut stem assay and expressed as the length of bark necrosis.

$p$-hydroxybenzoic acid, $500 \mathrm{ppm}$ for protocatechuic acid and 2,000 ppm for phloroglucin, respectively (Table 3). Although phloroglucin did not induce bark necrosis in lower concentrations, vascular browning of the stem was prominent.

\section{Sensitivity of some plants to toxic compounds}

In cut stem bioassay, the following 8 species were tested for their sensitivity to the toxic compounds at a concentration of $2,000 \mathrm{ppm}$; pear, quince, Japanese apricot, cherry, grape, chestnut, mulberry and walnut. All 8 species tested were sensitive to the toxin (Table 4).

\section{Discussion}

In the present study, phloretic acid, $p$-hydroxybenzoic acid and protocatechuic acid were isolated from culture extracts of Valsa ceratosperma grown in a medium containing apple bark components. Application of these compounds to apple shoots caused bark necrosis similar to natural canker. These compounds have been recognized as breakdown products of phloridzin ${ }^{1,6,7)}$. Our findings suggest that the breakdown products of phloridzin may function in canker development resulting from the fungus. Although $V$. ceratosperma was isolated from various broad-leaved $\operatorname{trees}^{10)}$, the severest canker developed on apple trees. This host specificity may be interpreted by the fact that phloridzin occurs specifically in high concentrations in apple tree ${ }^{3,8,19)} . V$. ceratosperma may produce enzymes which liberate phloretic acid from phloridzin in apple trees. Phloretic acid may be metabolized by the fungus into $p$-hydroxybenzoic acid and protocatechuic acid. The toxicity of breakdown products of phloridzin has also been demonstrated by Börner ${ }^{2}$ and Holowczak et al. ${ }^{6)}$ The latter reported that phloretic acid was toxic when infused into young apple trees. However, they suggested that a collapse of cells caused by phloretic acid prevented the development of apple scab.

In this paper we used the term toxin for convenience. However, the term toxin is generally defined as a non-enzymatic product of a microorganism or microorganismhost interaction which is harmful to plants in low concentrations ${ }^{14)}$. This criterion excludes the breakdown products of phloridzin, since they are toxic only in high concentrations. Graniti ${ }^{5}$ divided the substances involved in plant disease into two 
classes ; 1) pathogen-derived substance (phytotoxin and phytoagressin) and 2) plantderived substance. The latter includes substances that accumulate in infected plants as a result of action of enzymes produced by the pathogen on host constituents. The breakdown products of phloridzin may be placed in this category.

Here we propose the hypothesis that the breakdown products of phloridzin may play a role in canker development. Our hypothesis, however, does not explain why non-pathogenic fungi ${ }^{9)}$ or bacteria ${ }^{4)}$, which degradate phloridzin, do not cause apple canker. Other factors seem to be involved in the pathogenesis of apple canker. To prove our hypothesis the following criteria must be further investigated; 1) To demonstrate that a sufficient amount of breakdown products of phloridzin exist in the cankered tissue, 2) To demonstrate that non-pathogenic isolates do not degradate phloridzin. Such investigations are now in progress.

The authors thank N. Ohtake, Institute of Applied Microbiology, The University of Tokyo, for valuable suggestions.

\section{Literature cited}

1. Barnes, E. H. and Williams, E. B. (1961). Can. J. Microbiol. $7: 525-534$.

2. Börner, H. (1959). Contr. Boyce Thompson Inst. 20:39-56.

3. Challice, J.S. (1973). Phytochemistry 12;1095-1101.

4. Chatterjee, A. K. and Gibbins, L. N. (1969). J. Bacteriol. 100: 594-600.

5. Graniti, A. (1972). In Phytotoxins in Plant Diseases (Wood, R. K. S., Ballio, A. and Graniti, A. eds.). Academic Press, London. pp. 1-18.

6. Holowczak, J., Kuć, J. and Williams, E. B. (1960). Phytopathology $50: 640$ (Abstr.).

7. Holowczak, J., Kuć, J. and Williams, E. B. (1962). Ibid. 52: 1019-1023.

8. Hutchinson, A., Taper, C. D. and Towers, G.H. N. (1959). Can. J. Biochem. Physiol. 37 ; 901910.

9. Jayasankar, N. P., Bandoni, R. J. and Towers, G. H. N. (1969). Phytochemistry 8: 379-383.

10. Kobayashi, T. (1970). Bull. Govt. For. Expt. Sta. 226 : 1-242.

11. Ohtake, N., Natsume, H. and Seto, H. (1981). Ann. Phytopath. Soc. Japan 47: 383 (Abstr.).

12. Okuno, T., Oikawa, S., Goto, T., Toda, M., Sawai, K., Sawamura, K. and Matsumoto, T. (1980). Proc. 23 th Meeting of Natural Organic Chemistry pp. 530-537.

13. Ozawa, M. and Ito, S. (1976). Ann. Phytopath. Soc. Japan 46: 111 (Abstr.).

14. Rudolph. K. (1976). In Physiological Plant Pathology (Heitefuss, R. and Williams, P. H. eds.). Springer-Verlag, Berlin. pp. 270-315.

15. Saito, I., Tamura, O. and Takakuwa, M. (1972). Ann. Phytopath. Soc. Japan 38: 258-260.

16. Sakuma, T. (1979). Bull. Fruit Tree Res. Stn. Japan, Ser. C., 5: 29-38.

17. Tamura, O., Saito, I. and Takakuwa, T. (1975). Noyaku no Shinpo 15(2) : 1-12.

18. Togashi, K. (1924). J. Coll. Agric., Hokkaido Imp. Univ. Sapporo 12: 265-324.

19. Williams, A. H. (1964). Nature $202: 824-825$. 


\section{和 文 摘 要}

フロリジンのリンゴ腐らん病菌による分解産物が

病徵発現に関与する可能性について

小金沢碩城・佐久間 勉

リンゴ腐らん病菌をリンゴ樹皮煎汁培地で培養後, 培養ろ液をエーテル抽出し, このエーテル抽出物をリ ンゴ樹新梢に吸収させたところ，自然条件下で発病したりンゴ腐らん病に類似のネクロシスを生じた。エー テル抽出物をろ紙クロマトグラフィーをたはカラムクロマトグラフィーにより分画したところ， 3 画分に毒 性が認められた。これらの毒性物質は標品と薄層クロマトグラフィーでの挙動および紫外線吸収スペクトル を比較して, フロレチン酸, $p$-オキシ安息香酸, プロトカテチュ酸と同定した。これらの物質はリンゴ樹に 特異的に含まれているフロリジンが分解されて生ずるものとして知られている。フロリジン分解産物は高濃 度でのみ毒性を示し，かつ，供試したリンゴ以外の植物に対しても毒性を示した。 